\title{
ISLAMIC INFLUENCE ON WOODCARVING MOTIFS IN JOHOR TRADITIONAL MALAY HOUSES
}

Received July 28th, 2021 | Accepted November 18th, 2021 | Available online December 15th, 2021 |

DOI http://dx. doi. org/10.18860/jia.v6i4. 13028

\section{Hanita Yusof}

Architecture Department

Faculty of Civil Engineering and Built Environment Universiti Tun Hussein Onn Malaysia

Malaysia

e-mail: hanita@uthm.edu.my

\section{Corresponding Author.}

\section{Izudinshah Abd Wahab}

Architecture Department

Faculty of Civil Engineering and Built Environment Universiti Tun Hussein Onn Malaysia

Malaysia

\section{Nangkula Utaberta}

Architecture Department

Faculty of Civil Engineering and Built Environment Universiti Tun Hussein Onn Malaysia Malaysia

\author{
Azmal Sabil \\ Architecture Department \\ Faculty of Civil Engineering and Built Environment \\ Universiti Tun Hussein Onn Malaysia \\ Malaysia

\section{Nur Amalina Hanapi} \\ Architecture Department \\ Faculty of Civil Engineering and Built Environment \\ Universiti Tun Hussein Onn Malaysia \\ Malaysia
}

\begin{abstract}
Woodcarving motifs can be influenced by various aspects, including religions and beliefs. Malaysia is known for its cultural diversity and is rich with traditional heritage. Malay is one of the major ethnic groups in Malaysia and is considered as the majority of the country's population, contributing to the significant heritage, including art, decoration, and even architecture. Traditional woodcarving is an intricate Malay heritage and is the symbol of Malay art. A study on Malay woodcarvings is critically needed in order to know the influence that occurs on the selection of the motifs. It is such a waste to see our woodcarving heritage destroyed unappreciated and undocumented, especially on Johor woodcarvings, as many studies in other states have done. More and more traditional Johor Malay houses are being demolished day by day before we know the historical influence on the existence. The objective of this paper was to identify the woodcarving motifs found in Johor Malay houses and to identify their influence. Site visits were conducted in which the woodcarvings of 50 houses were examined, photographed, and documented. Interviews were also conducted with the house owners and the woodcarvers. The samples were analyzed, and the results were verified by experts. The results show that floral motifs lead the statistic, and the pumpkin motif, known as 'labu maya', takes the highest percentage of the overall motifs. It is concluded that the Islamic religion is the biggest influence that contributes to the findings. The findings also show that the 'labu maya' motif is the identity of the Johor woodcarving motifs. It is hoped that this study can bring recognition to Johor woodcarvings, and contribute valuable guides for woodcarvers to apply these motif typologies into their future works to sustain and cherish the Johor local identity.
\end{abstract}

\section{KEYWORDS:}

Wood Carving, Malay Woodcarving, Malay Woodcarving Motif, Islamic Motif, Johor Traditional House.

\section{INTRODUCTION}

Malaysia is one of the countries that possess various ethnics, has cultural diversity, and is rich with traditional heritage. Malay is one of the major ethnic groups in Malaysia and is considered as the majority of the country's population, which contributes to the significant heritage, including art, decoration, and even architecture. Traditional woodcarving is an intricate Malay heritage and is the symbol of Malay art. Woodcarving was created and designed to provide convenience and enhance the art of Malay culture [1]. Despite being an important element, woodcarving is on the brink of being disregarded due to opting for modern and more contemporary design. These practices pose a threat to the local identity and the historical value of the local heritage. Suppose such practices continue and the identity of the local heritage is not identified and recorded. In that case, the traditional designs and local identity left by the local ancestors will eventually be lost. Therefore, the objective of this study was to identify the woodcarving motifs in Johor traditional houses and identify the category and their influences.

\section{RESEARCH BACKGROUND}

Traditional Malay houses are commonly decorated with woodcarvings that have beautiful motifs, placements, and design compositions. According to Noor Hanita et al. [2], woodcarving revealed the identity of Malay culture that has been assimilated into the traditional or vernacular buildings to add the aesthetic value to its architecture.

These woodcarvings represent the Malay culture and should be perceived, appreciated, and preserved. However, vast urbanization has created such a huge impact where the old houses were being renovated using modern elements and components due to the rapid development of architectural style and recent 
technology [3][4][5] to keep up with the current trend. Hence, it is important to conduct research on woodcarvings found in the traditional Malay houses. Studies on woodcarving have been carried out in the vicinity of Kelantan, Terengganu, Kedah, Perak, Negeri Sembilan, and Melaka, while this research will cover Johor.

\section{Issues and Problem Statement}

One of the biggest issues that create a challenge in preserving this Malay heritage in Johor is the abandonment of traditional houses with woodcarving. It is such a waste to see our heritage of woodcarving being destroyed, unappreciated and undocumented. More and more traditional Malay houses are being demolished day by day, making it harder to explore the historical value. Study on motifs is very important as the motif may represent the identity of the woodcarving of a certain vicinity.

Through interviews, the issue of an identity crisis, as well as the influence, occurred because the Johor woodcarvers have not made any detailed study related to woodcarving motifs on Johor traditional houses that have existed for more than 100 years [6].

\section{Influence on the Woodcarving Motifs}

The woodcarving motif in Malay woodcarving in the Malay Archipelago came before the pre-Islamic era when they embraced Hinduism and Buddhism. The motifs found at that time were included Kala Makara, Gunungan, Stupa, Garuda and Naga [7].

With the arrival of Islam, these motifs were slowly reformed in accordance with the Islamic rules and regulations [8][9][10]. Most of the carvings representing motifs of Kala and Makara were transformed into floral elements. The transformations were also influenced by the craftsman's skill, natural elements, and of course the religious belief and thought [11]

The adaptations of different religions influenced the evolutions of woodcarvings in Malaysia. According to Perbadanan Kemajuan Kraftangan Malaysia [12], a series of influences started with Hinduism. Most of the woodcarvings were depicted by Hindu motifs and followed by the arrival of Langkasuka motifs, and from there, it evolved and transformed to Buddhism motifs after the arrival of the Chinese. It was then influenced by the colonial motifs when the westerners came and finally turned into 'Malay motif' derived from the strong Islamic influence.

Unlike the woodcarvings from the north-eastern state of Malaysia, which are known to have Langkasuka and Hindu influences, not much is known for Johor. As for Johor, it has not been investigated whether there are any Hinduism and Buddhism influence motifs found in their traditional houses or only Islamic influence motifs are found. It is also to investigate and identify the most outnumbered motif that may represent the identity of the Johor woodcarving motif.

\section{METHODOLOGY}

The research employed a case study design, and the data collection methods involved field study and interviews. The research started with obtaining information about the traditional Malay houses that can be found throughout Johor. Next, site visits and inventory were conducted at 110 traditional Malay Johor houses. From there, 50 houses were then selected for the case study. Finally, the houses and woodcarvings were examined, observed, photographed, and documented.

These 50 Johor traditional Malay houses were chosen based on three criteria: their age, distinctive woodcarvings, and having woodcarvings in various significant placements. The houses must be over 50 years old. The houses were built as early as 1820 . The woodcarvings should be authentic and built around the same age of the house and were not a reproduction or addition built during renovation.

The house residents were interviewed to obtain information related to the year the house and the woodcarvings were built, the influences and functions apart from the details of the house owner, address, and captured ample related photographs. In addition, interviews and analytic reviews were also conducted with professionals consisting of the local woodcarvers and woodcarving experts around Muar.

Data gathered from the site visits were then analyzed with narration and interpretation from these prominent local woodcarvers. Next, the data collected and woodcarving samples were analyzed and discussed with experts for verification. Finally, the timeline table of the houses was done to generate statistical graphs, bar charts, and pie charts to get a typical percentage of statistical analysis review.

\section{RESEARCH FINDINGS}

All 50 Johor traditional houses possessed interesting woodcarvings. Analysis, findings, and interpretations of the results are as follows:

\section{Analysis of Findings on Category of Woodcarving} Motif

Based on the investigation, all case study houses possessed five categories of motifs: flora, fauna, geometry, calligraphy, and cosmos.

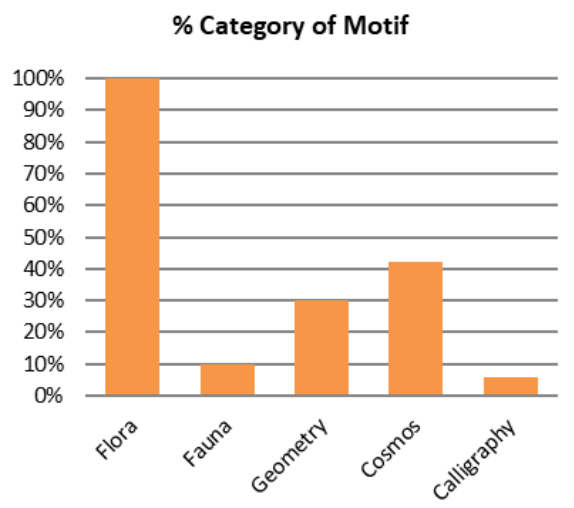

Figure 1: Bar chart showing the percentage of motifs under the category of flora, fauna/animals, geometry, calligraphy, and cosmos 
Referring to the bar chart in figure 1, the percentage for motifs found in woodcarvings in the case study showed that the highest category of the motif is the floral motif, which is $100 \%$, where all 50 houses have the floral motif. It is followed by the cosmos motif as the second-largest motif category, namely $42 \%$, and $30 \%$ for the geometrical motif. Only $10 \%$ of the case study houses have fauna/animal motifs, while only $6 \%$ have calligraphic motif.

\section{Interpretation on Category of Woodcarving Motif}

All 50 houses were found to have motifs under the floral category of $100 \%$. According to the analysis of site inventory and triangulated with the historical facts and interviews, floral motifs dominated the selection of carvings in all houses because the houses were built after the arrival of Islam to Johor, where after Islam arrived in the early 14th century. The motif preferences have changed from mythical or mystical or animism motifs to floral and geometrical motifs in line with Islamic influences.

Floral motifs dominated the percentage, followed by geometrical motifs because the earliest year of woodcarving in Johor was 1800, after Islam's arrival. According to analysis, geometrical motifs are the second-highest percentage, followed by the calligraphic and cosmos motifs. Due to that, it can be summarized that the motif of flora, geometry, calligraphy, and cosmos are all allowed in Islam since those have no elements of creatures or animals. In contrast, the motif of fauna/animals is the least motif found with the lowest percentage because it is prohibited to be used in Islam.

It can be articulated that the selection of motifs in Johor traditional Malay houses is strongly influenced by the Islamic belief as the construction of houses and all carvings are upon the arrival of Islam to Johor. However, there are also mixed motifs where the floral and geometrical motifs are combined within a pattern, such as at the jerejak serambi in figure 2 , which also does not violate Islamic belief.

Nevertheless, there is also a fauna/animal motif used in five houses with animal motifs, i.e., motifs of rooster, butterfly, deer, bird, and peacock. Eccentrically, there is a combination of a calligraphic motif together with fauna/animal in one carving on the top of the door (kepala pintu), as shown in figure 3 below.

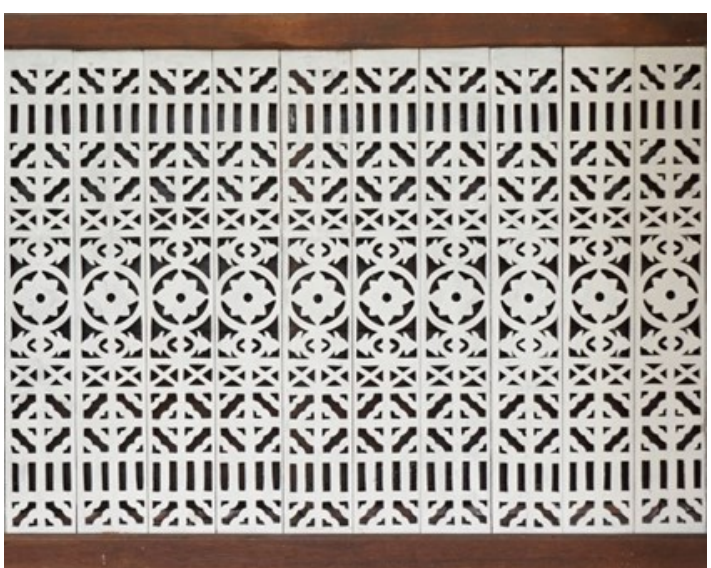

Figure 3: Combination of a calligraphy and fauna motif

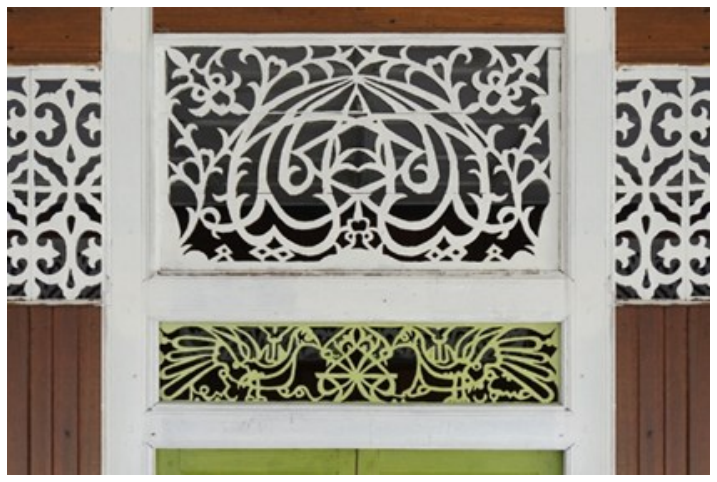

Figure 3: Combination of a calligraphy and fauna motif

Figures 4 and 5 show that the flora/animals are used as woodcarving motifs in the case study houses. However, there are only five houses with animal motifs: rooster, butterfly, deer, bird, and peacock.

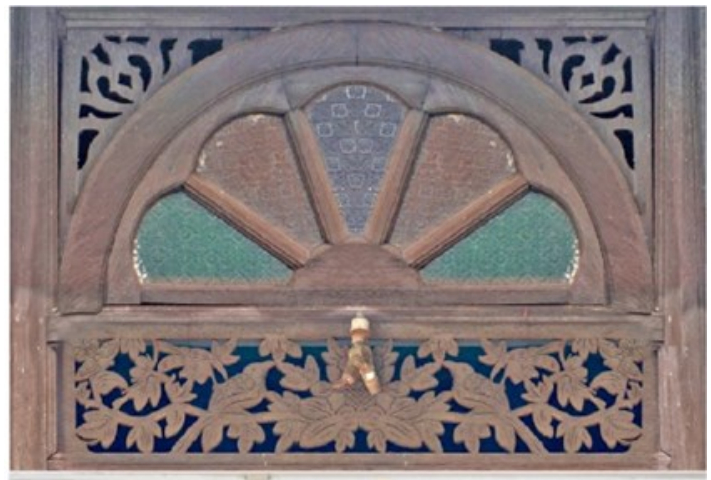

Figure 4: Woodcarvings with fauna motifs 

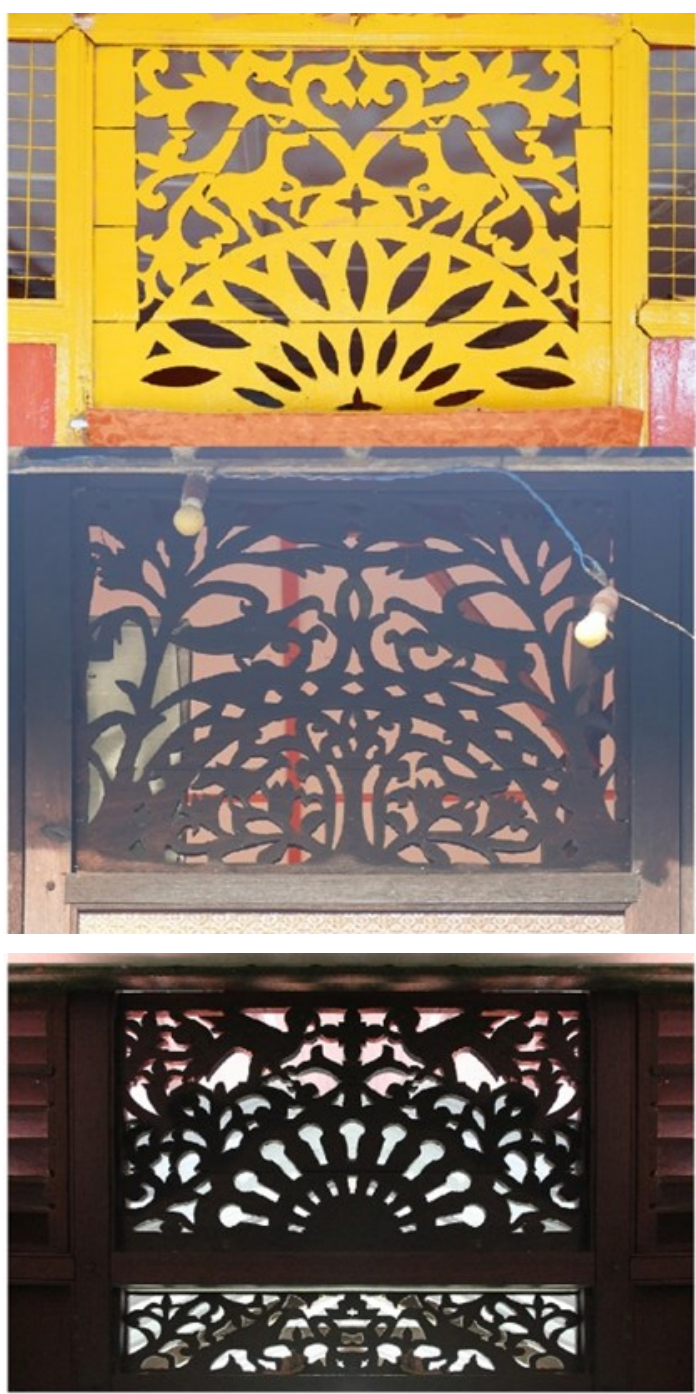

Figure 5: Woodcarvings with fauna motifs

The findings show that the category of fauna / animal motif is only $10 \%$ found in case study houses. It is strictly prohibited in Islamic belief since all study houses were built after the arrival of Islam. However, even though there are fauna/animal motifs, the selection is solely because the selected animal is a good animal, beautiful and has a high status, and is neither a terrible animal nor a mystical or mythical animal.

\section{Findings and Analysis on Pumpkin and Other Floral Motifs}

The finding of pumpkin motifs through motif analysis as the highest percentage compared to other motifs makes the pumpkin motif a typical woodcarving motif for Johor. This motif recognition was agreed upon by interviews and discussions with woodcarving experts.

The pumpkin motif preceded the percentage of the analysis statistics at $41 \%$. Besides the pumpkin motif, painted nettle leaf (daun ati-ati) motif as much as $23 \%$, beans chickpea motif and jasmine (melur) motif $9 \%$, while other floral motifs of star anise, bamboo shoot, white clover, spanish cherry, pineapple, and turmeric $3 \%$.

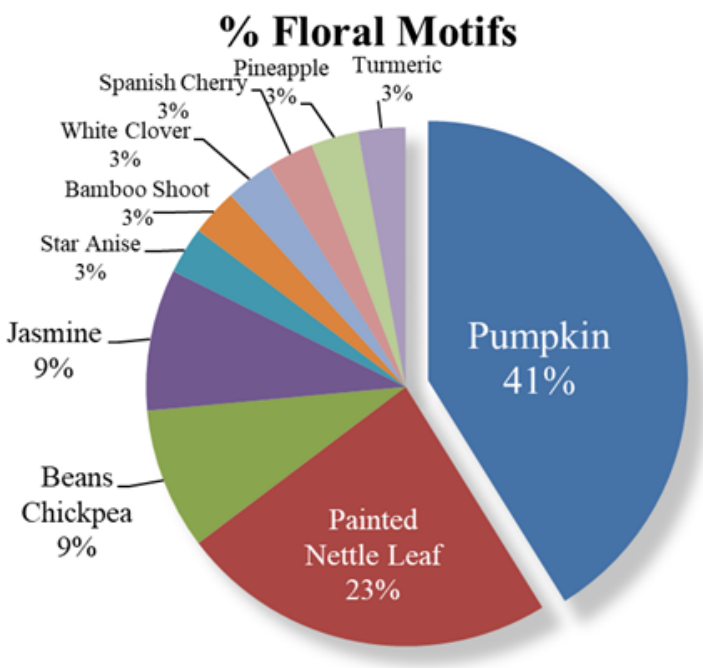

Figure 6: Pie chart showing the percentage of floral motifs

The following is the analysis template for implementing motif recognition methods discussed with woodcarving experts for the verification process.

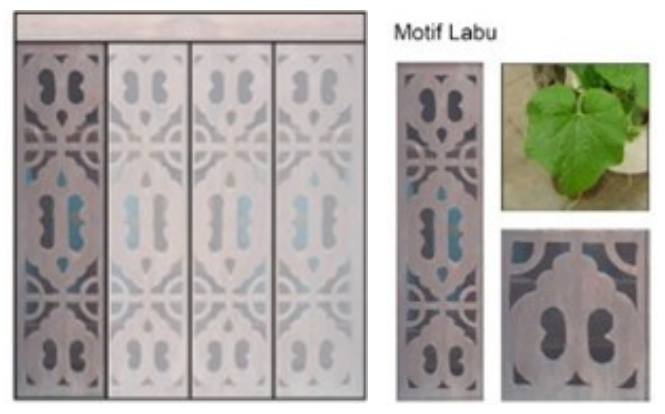

\begin{tabular}{|l|l|}
\hline Perletakan: & Jerejak Tingkap Anjung \\
Teknk Ukiran. & Tebuk Tembus Tanpa Silat \\
Komposisi Rekabentuk: & Simetri dan Pengulangan \\
Pola: & Pemidang \\
Kategori Motr: & Flora \\
Motif: & Buah Labu dan Daun Labu \\
Pendokatan Rekaan: & Transtormasi Abstrak \\
Punca: & Punca Daun \\
Ked 'S: & Daun Lebar (Kod 'H') \\
Komponen Ukiran: & Daun dan Buah \\
& Pokok Labu \\
Nama Pokok: & Cucurbita pepo \\
Nama Botankal: & Tumbuhan herba menjalar \\
Kareiteristk: & Masakan dan Perubatan \\
Fungai: & Kaya dengan gizi yang lengkap, penghilang \\
Khasiat: & dehidrasi tubuh \\
& Bahagian belakang rumah / dapur \\
Kehadiran di Persekitaran & Makanan yang melambangkan kemewahan \\
\hline
\end{tabular}

Figure 7: Pumpkin motif carving analysis 


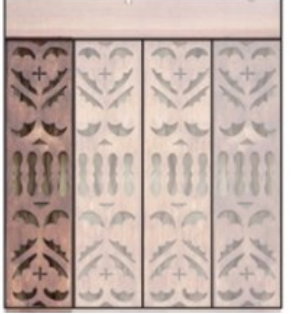

Motif Ati-Ati
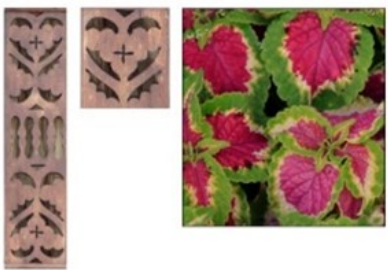

\begin{tabular}{|c|c|}
\hline Perletakan: & Jerejak Tingkap Anjung \\
\hline Teknik Ukiran: & Tebuk Tembus Tanpa Silat \\
\hline Komposisi Rekabentuk: & Simetri dan Pengulangan \\
\hline Pola: & Pemidang \\
\hline Kategon Moti: & Flora \\
\hline Motr: & Daun Att-Ati \\
\hline Pendekatan Rekaan: & Transformasi Abstrak \\
\hline Punca: & Punca Daun \\
\hline Kod 's: & Daun Bentuk Hati \\
\hline Komponen Ukiran: & Daun \\
\hline Nama Pokok: & Pokok Ati-Ati \\
\hline Nama Botanikal: & Plectranthus scutellarioides I Coleus blumei \\
\hline Karekteristik: & Tumbuhan herba dalam keluarga kacang \\
\hline Fungsi: & Hiasan dan Perubatan \\
\hline Khasiat: & $\begin{array}{l}\text { Mengubati batuk, bisul, cirit-birit serta } \\
\text { melancarkan pencornaan }\end{array}$ \\
\hline Kehadiran di Persekitaran | & Bahagian hadapan rumah \\
\hline Status / Keistimewaan: & Wama kontrasnya memberikan daya tarikan \\
\hline
\end{tabular}

Figure 8: Painted nettle leaf motif carving analysis
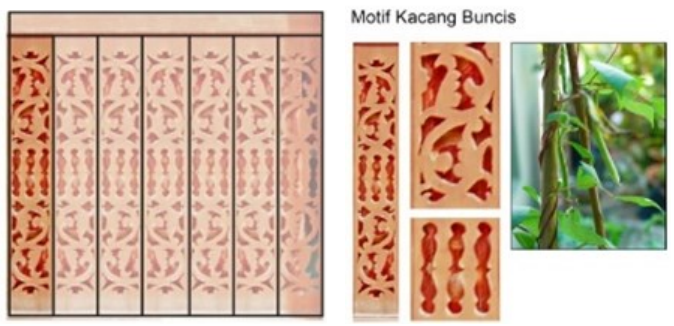

\begin{tabular}{l|l|}
\hline Perletakan: & Jerejak Tingkap Anjung \\
Teknik Ukiran: & Tebuk Tembus Tanpa Silat \\
Komposisi Rekabentuk & Simetri dan Pengulangan \\
Pola: & Pemidang \\
Kategori Motif: & Flora \\
Motit: & Kacang Buncis \\
Pendekatan Rokaan: & Transformasi Abstrak \\
Punca: & Punca Rahsia \\
Kod 'S: & Daun Bergerigi Lembut \\
Komponen Ukiran: & Daun, Sulur, Batang dan Buah \\
& Pokok Kacang Buncis \\
Nama Pokok: & Phaseolus vulgaris \\
Nama Botanikal: & Melilit dan Berakar Tunjang \\
Karekteristik: & Masakan dan Perubatan \\
Fungsi: & Kaya dengan protein, vitamin, serat, mineral \\
Khasiat: & dan antioksidan \\
& Bahagian belakang rumah / dapur \\
Kehadiran di Persekitaran & Sebagai sayuran dalam masakan \\
\hline Status / Keistimewaan: &
\end{tabular}

Figure 9: Beans chickpea motif carving analysis

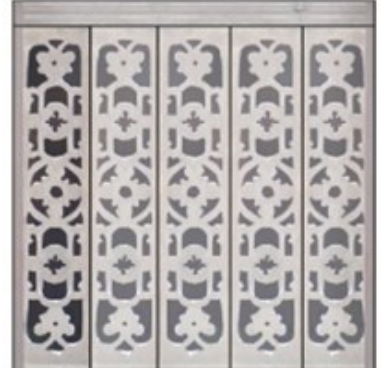

Motif Bunga Melur

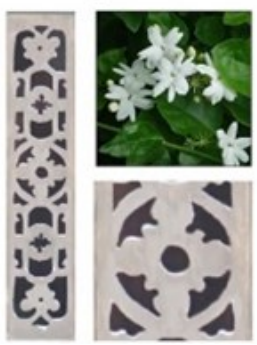

\begin{tabular}{|l|l|}
\hline Perletakan: & Jerejak Tingkap Anjung \\
Teknk Ukiran: & Tebuk Tembus Tanpa Silat \\
Komposisi Rekabentuk: & Simetri dan Pengulangan \\
Pola: & Pemidang \\
Kategori Most: & Flora \\
Motr: & Bunga Melur \\
Pendekatan Rekaan: & Transformasi Abstrak \\
Punca: & Punca Bunga \\
Kod S: & B8kpa / Bunga Kelopak 8 Pandangan Atas \\
Komponen Ukiran: & Bunga Kembang \\
& $\begin{array}{l}\text { Pokok Melur } \\
\text { Nama Pokok: }\end{array}$ \\
Nama Botanikat: & Jasminum sambac \\
Karekteristik & Tumbuhan renek yang merayap dan menjalar \\
Fungsi: & Hiasan dan Kecantikan \\
Khasiat: & Bunga melur diramas pada bekas gigitan \\
& tebuan bagi menghilangkan bisa dan bengkak \\
Kehadiran di Persektaran & Bahagian hadapan rumah \\
Status / Keistimewaan: & Bauan bunga yang kuat dan harum \\
\hline
\end{tabular}

Figure 10: Jasmine motif carving analysis
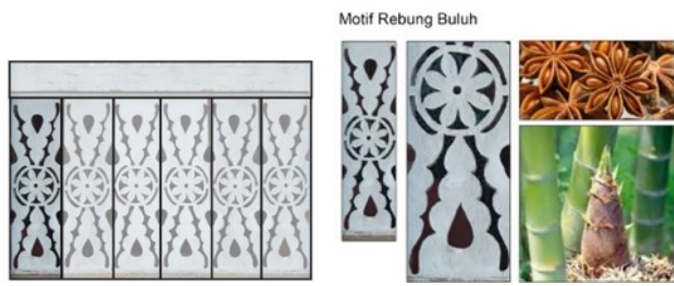

\begin{tabular}{|l|l|}
\hline Perletakan: & Jerejak Tingkap Anjung \\
Teknik Ukiran. & Tebuk Tembus Tanpa Silat \\
Komposisi Rekabentuk: & Simetri dan Pengulangan \\
Pola: & Pemidang \\
Kategori Motr: & Flora \\
Motr: & Bunga Lawang \\
Pendekatan Rekaan: & Transformasi Abstrak \\
Punca: & Punca Benih \\
Kod 'S: & Bskpa / Bunga Kelopak 8 Pandangan Atas \\
Komponen Ukiran: & Bunga \\
Nama Pokok: & Pokok Bunga Lawang \\
Nama Botanikal: & llicium verum \\
Karekteristik: & Memiliki lapan kelopak dan bau yang kuat \\
Fungsi: & Masakan dan Perubatan \\
Khasiat: & Kaya dengan perisa dan fungsi diuretik \\
Kehadiran di Persektaran & Bahagian belakang rumah / dapur \\
Status / Keistimewaan: & Rempah ratus yang popular \\
\hline Motif: & Rebung Buluh / Tunas Buluh \\
Kod 'S: & Pucuk Tajam (Kod 'H) \\
Komponen Ukiran: & Pucuk dan Batang \\
Nama Pokok: & Pokok Buluh \\
Nama Botanikal: & Bambusa vulgaris \\
Karekteristik: & Tumbuh meliar \\
Fungsi: & Masakan dan Perubatan \\
Khasiat: & Kaya dengan serat \\
Kehadiran di Persekitaran & Di tepi parit dan tepi hutan \\
Status / Keistimewaan: & Rasa unik namun tanaman semakin pupus \\
\hline
\end{tabular}

Figure 11: Star anise motif and bamboo shoot carving analysis 

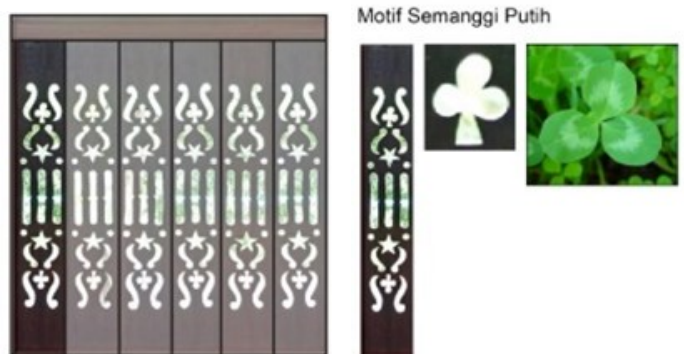

\begin{tabular}{l|l|}
\hline Perletakan: & Jerejak Tingkap Anjung \\
Teknik Ukiran: & Tebuk Tembus Tanpa Silat \\
Komposisi Rekabentuk: & Simetri dan Pengulangan \\
Pola: & Pemidang \\
Kategori Mosir: & Flora \\
Mout: & Daun Semanggi Putih \\
Pendekatan Rekaan: & Transformasi Abstrak \\
Punca: & Punca Daun \\
Kod 'S: & Daun Tiga \\
Komponen Ukiran: & Daun \\
& Pokok Semanggi Putih \\
Nama Pokok: & Trifolium repens \\
Nama Botanikal: & Tumbuhan herba dalam keluarga kacang \\
Karekteristik: & Masakan dan Perubatan \\
Fungsi: & Sebagai ulam-ulaman yang kaya protein \\
Khasiat: & Bahagian belakang rumah / dapur \\
Kehadiran di Persektaran & Daunnya yang lebar sangat unik \\
\hline
\end{tabular}

Figure 12: White clover motif carving analysis
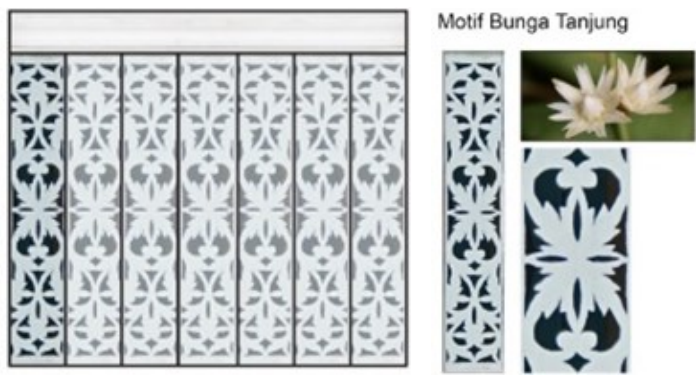

\begin{tabular}{|c|c|}
\hline Perletakan: & Jerejak Tingkap Anjung \\
\hline Teknik Ukiran: & Tebuk Tembus Tanpa Silat \\
\hline Komposisi Rekabentuk: & Simetri dan Pengulangan \\
\hline Pola: & Pemidang \\
\hline Kategon Most: & Flora \\
\hline Motit: & Bunga Tanjung \\
\hline Pendekatan Rokaan: & Transformasi Abstrak \\
\hline Punca: & Punca Bunga \\
\hline Kod's: & B8kpa / Bunga Kelopak 8 Pandangan Atas \\
\hline Komponen Ukiran: & Bunga Kembang \\
\hline Nama Pokok: & Pokok Tanjung \\
\hline Nama Botanikal: & Mimusops elengi \\
\hline Karekteristik: & Pokok malar hijau yang boleh mencecah $16 \mathrm{~m}$ \\
\hline Fungai: & Perubatan dan Kecantikan \\
\hline Khasiat: & $\begin{array}{l}\text { Mewangikan rambut dan merawat luka, ruam } \\
\text { bemanah dan sakit gigi }\end{array}$ \\
\hline Kehadiran di Persekitaran & Bahagian hadapan mahupun belakang rumah \\
\hline Status / Keistimewaan: & Bunganya yang berbau wangi \\
\hline
\end{tabular}

Figure 13: Spanish cherry motif carving analysis

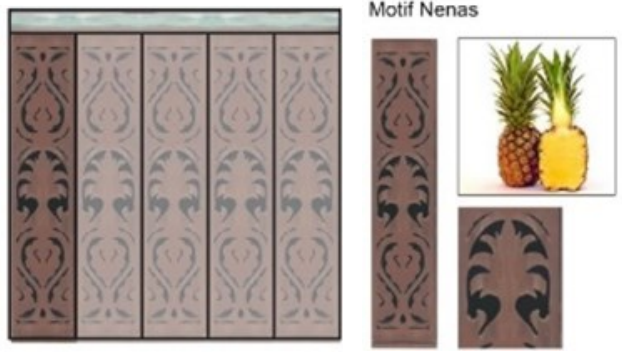

\begin{tabular}{|l|l|}
\hline Perletakan: & Jerejak Tingkap Anjung \\
Teknik Ukian: & Tebuk Tembus Tanpa Silat \\
Komposisi Rekabentuk & Simetri dan Pengulangan \\
Pola: & Pemidang \\
Kategori Most: & Flora \\
Motif: & Buah Nenas dan Jambul Nenas \\
Pendekatan Rekaan: & Transformasi Abstrak \\
Punca: & Punca Buah \\
Kod 'S: & Daun Jambul (Kod 'H') \\
Komponen Ukiran: & Buah dan Jambul \\
& \\
Nama Pokok: & Pokok Nenas / Nanas \\
Nama Botanikat: & Ananas comosus \\
Karekteristic & Tumbuhan renek 'herbaceous perennlar' \\
Fungsi: & Masakan dan Kecantikan \\
Khasiat: & Mengandungi vitamin, antioksidan dan bagus \\
& untuk kecantikan kulit \\
Kehadiran di Persektaran & Bahagian belakang rumah dan kebun \\
Status / Keistimewaan: & Tanaman yang menjana pendapatan negeri \\
\hline
\end{tabular}

Figure 14: Pineapple motif carving analysis
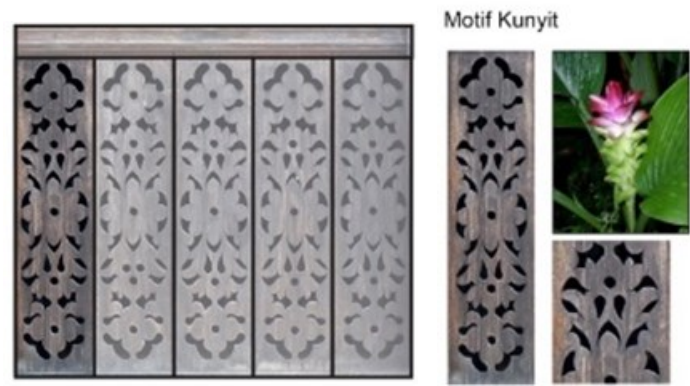

\begin{tabular}{|l|l|}
\hline Perletakan: & Jerejak Tingkap Anjung \\
Teknik Ukran: & Tebuk Tembus Tanpa Silat \\
Komposisi Rekabentuk: & Simetri dan Pengulangan \\
Pola: & Pemidang \\
Kategori Motr: & Flora \\
Motif: & Bunga Kunyit \\
Pendekatan Rekaan: & Transformasi Abstrak \\
Punca: & Punca Bunga \\
Kod 'S: & Bunga Kelopak Bertingkat-tingkat \\
Komponen Ukiran: & Bunga Kembang \\
& Pokok Kunyit \\
Nama Pokok: & Curcuma longa \\
Nama Botanikal: & Herba 'Rhizomatous herbaceous perenniar' \\
Karekteristik: & Masakan, Perubatan dan Kecantikan \\
Fungsi: & Pembersih dalaman badan, mencantikkan \\
Khasiat: & kulit dan agen anti-radang \\
Kehadiran di Persektaran & Bahagian belakang rumah / dapur \\
Status / Keistimewaan: & Sebagai pewarna dan perisa dalam masakan \\
\hline
\end{tabular}

Figure 15: Turmeric motif carving analysis 


\section{Research Interpretation on Pumpkin Motif}

The finding of pumpkin motif as the most carved motif, which is $42 \%$, can be formulated that it is in line with the literature study which states that one of the criteria of a species to be chosen as a motif is due to the nature or uniqueness of the leaves and fruits [13] and belongs to the category that Malay society is interested in such as edible, has medical and aesthetic values [14]. Therefore, pumpkin is included in this special category. Furthermore, through interviews with local carvers and villagers, it was found that most of the Johor Malays eat yams and rice, and if there is a special day, they will serve pumpkin as a luxury food [15].

One of its specialties is because of its deliciousness, on top of the fact that pumpkin has high nutrients which also makes it more special. According to Anas bin Malik r.a who said in the hadith narrated by At-Tirmidzi, one important thing about pumpkin is that the Prophet Muhammad s.a.w was very fond of pumpkins. The era of woodcarving in these case study houses is after the arrival of Islam, and indeed the influence of Islam was also related to the discovery of this most widely used motif. Tuzelan Ahmad [16] also stated that the influence of Johor carving is from the Islamic belief brought by the traders. Hence, religious knowledge becomes a grip in applying motif and sunnah as it is demanded in daily life.

\begin{tabular}{|c|c|}
\hline Perletakan: & Jerejak Tingkap Anjung \\
\hline Teknik Ukiran: & Tebuk Tembus Tanpa Silat \\
\hline Komposisi Rekabentuk: & Simetri dan Pengulangan \\
\hline Pola: & Pemidang \\
\hline Kategori Motif: & Flora \\
\hline Motif: & Buah Labu dan Daun Labu \\
\hline Pendekatan Rekaan: & Transformasi Abstrak \\
\hline Punca: & Punca Daun \\
\hline Kod 'S': & Daun Lebar (Kod 'H') \\
\hline Komponen Ukiran: & Daun dan Buah \\
\hline Nama Pokok: & Pokok Labu \\
\hline Nama Botanikal: & Cucurbita pepo \\
\hline Karekteristik: & Tumbuhan herba menjalar \\
\hline Fungsi: & Masakan dan Perubatan \\
\hline Khasiat: & $\begin{array}{l}\text { Kaya dengan gizi yang lengkap, penghilang } \\
\text { dehidrasi tubuh }\end{array}$ \\
\hline Kehadiran di Persekitaran: & Bahagian belakang rumah / dapur \\
\hline Status / Keistimewaan: & Makanan yang melambangkan kemewahan \\
\hline
\end{tabular}

Figure 16: Information on the pumpkin details and its selection as a motif

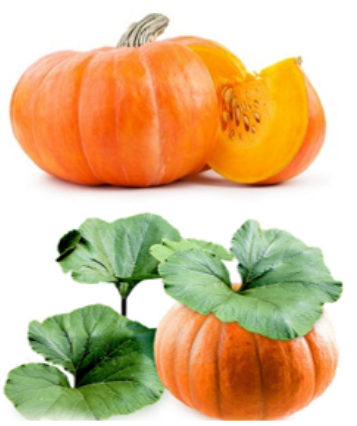

Figure 17: Pumpkin fruit and its leaves

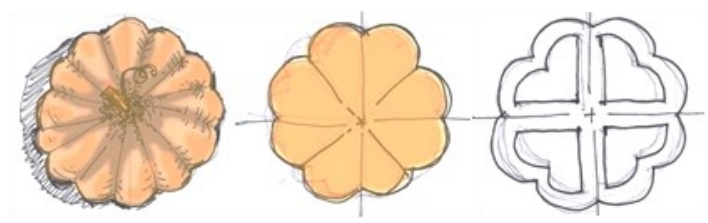

Figure 18: The top view of pumpkin fruit showing the transformation from the actual look of realism image towards an abstract image

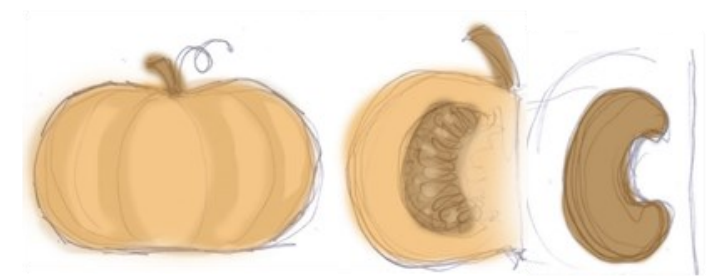

Figure 19: The side view of the pumpkin fruit's exterior, crosssections, and interior images are sketched towards abstract transformations

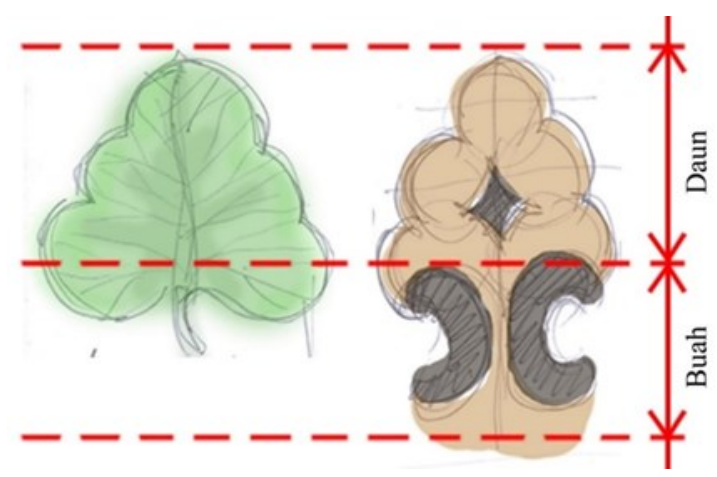

Figure 20: Pumpkin leaves and sketch for carvings using a combination of pumpkin motif through leaves and cross-sections of fruit being carved in an abstract transformation approach

Since the pumpkin motif is very dominant in the case study houses, it is of interest if given a special term. However, the pumpkin carving is not in realism image approach; instead, it is an abstract transformation approach of a pumpkin, so it has to be distinguished by a different name from the pumpkin motif in the realism image approach that may be carved anywhere else. Thus, this study contributed to discovering and finding the pumpkin motif as 'labu maya', a specially carved pumpkin motif extracted from the fruit exterior, fruit cuttings, and leaves to make it a special motif Johor.

\section{CONCLUSION}

The findings revealed that Islamic influence has major contributions in the decision-making of motif selection in Johor traditional Malay houses. It can be seen through the motif's category and the motifs designed individually in the woodcarvings of the case study houses. Floral motif dominated the percentage for motifs found in woodcarvings which is $100 \%$ meaning that all case study houses have the floral motif. It is followed by the cosmos motif as the second -largest motif category, namely $42 \%$, and $30 \%$ for a 
geometrical motif. According to the analysis of site inventory and triangulated with the historical facts and interviews, floral motifs dominated the selection of carvings in all houses because the houses were built after the arrival of Islam to Johor, where after Islam arrived in the early $14^{\text {th }}$ century. The motif preferences have changed from mythical or mystical or animism motifs to floral and geometrical motifs that are in line with Islamic influences. Religion has always had a big impact on society and the lifestyle of the community. Therefore, religion undoubtedly influences the community's culture, civilization, and beliefs system, including in determining the motifs.

It can be articulated that the selection of motifs in Johor traditional Malay houses is strongly influenced by the Islamic belief as the construction of houses and all carvings are upon the arrival of Islam to Johor. These findings are significant to the local architectural heritage of Johor architecture as it portrays the unity of the local people since 1820 . All case study houses have it, and it is important to promote the local identity and sustain the local belongings without imitating the identities of other countries. It is hoped that the findings will help to acknowledge Johor woodcarving's unique identity, to be used for future generations. In addition, the results can also provide valuable guides for woodcarvers to apply these motif typologies into their future works to sustain and cherish the Johor identity. Therefore, the local identity and the authentic value of the local heritage can be preserved.

\section{ACKNOWLEDGEMENT}

This publication was supported by Award Number $\mathrm{H} 751$ of the Tier 1 grant from Universiti Tun Hussein Onn Malaysia.

\section{REFERENCES}

[1] W. Jenkins, "Keeping the Traditions of Malay Woodcarving Alive: The mission of Akademi Nik Rashiddin", in Zawiyah Baba. (Ed.) Warisan Seni Ukir Kayu Melayu, pp. 59-66, ATMA, Universiti Kebangsaan Malaysia, 2010.

[2] N. H. A. Majid, Z. A. Rahim, Z. Denan, "Climate Responsive Strategies versus the Cultural and Religious Dimensions in the Architecture of Malay Traditional House", in Malay Vernacular Architecture: Traditional and Contemporary Expressions, International Conference on Construction and Industry (ICCI II 2009), 2009.

[3] M. T. M. Rasdi, "The Discontinued Traditions of Malay Wood Carvings in Modern and Post-
Modern Architecture in Malaysia", Jurnal Alam Bina, Vol. 8, No.2, pp. 61-92, 2006.

[4] Z. Kamarudin and I. Said, "Placement of Carved Components in Traditional Timber Houses of Kelantan and Terengganu", Warisan Seni Ukir Kayu Melayu, pp. 129-142, 2010.

[5] Z. Kamarudin and I. Said, "Carving Motifs in Timber Houses of Kelantan and Terengganu: Sustaining Malay Architecture Identity", Conference on Technology \& Sustainability in the Built Environment, pp. 235-256, 2010.

[6] H. Yusof, Identiti Ukiran Kayu bagi Rumah Limas Johor. PhD Thesis, Universiti Teknologi Malaysia, 2018.

[7] A.N. Farish and E. Khoo, The Art of Malay Woodcarving, Singapore: Periplus Edition, 2003.

[8] R. Othman, "The Language of the Langkasuka Motif", Indonesia and the Malay World, Vol. 33, No 96, pp. 97-111, 2005, DOI: https:// doi.org/10.1080/13639810500281898

[9] N. Noordin, Ukiran Kayu Warisan Melayu. Perbadanan Kemajuan Kraftangan Malaysia. Mantera Communication Sdn. Bhd, 2009

[10] N. Noordin (2017). Komunikasi Peribadi. Negeri Sembilan: Seri Menanti Resort, 2017

[11] N. Shaffee, \& I. Said, "Types of Floral Motifs and Patterns of Malay Woodcarving in Kelantan and Terengganu", Procedia - Social and Behavioral Sciences, vol. 105, pp. 466-475, 2013, Doi: https://doi.org/10.1016/j.sbspro.2013.11.049.

[12] Kraftangan Malaysia, Ukiran Kayu Warisan Melayu, Kuala Lumpur Perbadanan Kemajuan Kraf Tangan Malaysia, 2009.

[13] I. Said and A. Saifuddin, Spesis-Spesis Kayu Dalaman Ukiran Melayu, Skudai: UTM Press, 2001.

[14] H. Hussin, Z. Baba, A. Hassan, A. Eshah, \& H. Mohamed, "The philosophy in the creation of traditional Malay carving motifs in Peninsula Malaysia", Geografia - Malaysian Journal of Society and Space, Vol. 8, No. 7, pp. 88-95, 2017.

[15] A. B. Yatim, Komunikasi Peribadi. Tanjung Gading, Muar, Johor, 2015.

[16] T. Ahmad, Komunikasi Peribadi. Galeri Perusahaan Zalikraf, Muar, Johor, 2017 